\title{
Emotional Intelligence (EI) Development for Information Professionals: Towards a Holistic EI Training Program
}

\author{
Zoé de Geofroy ${ }^{1,2}$ and M. Max Evans ${ }^{1}$ \\ ${ }^{1}$ School of Information Studies, McGill University, Montreal, Quebec, Canada \\ ${ }^{2}$ Swiss Doctoral School in Affective Sciences, University of Geneva, Geneva, Switzerland
}

This research aims to: 1) demonstrate a connection between emotional competencies and successful information and knowledge-related work, and 2) identify common components of emotional competency training programs, to develop such a program for information professionals.

Emotions have long been overlooked in organizations (Arvey \& Murphy, 1998), perceived as being irrational, personal, and feminine (Putnam \& Mumby, 1993), or thought to hinder efficiency, by getting in the way of sound judgment (Grandey, 2000). Goleman (1995) discredited this perception with his work on Emotional Intelligence (EI). Along with others (e.g., Bogdan, 2008; Elfenbein, 2007; Salovey \& Mayer, 1990), Goleman legitimized emotions as an integral aspect of organizational life, viewed as the main rationale for essential organizational outcomes (e.g., policies, procedures, culture, individual performance, etc.) (Bogdan, 2008; Praner, 2008). Emotions are also found to play a significant role in influencing worker motivation, interpersonal work relationships, career satisfaction, and overall willingness to engage in pro-social behaviour (Mozie \& Razak, 2014; Palmer et al., 2005; Praner, 2008).

EI is "the capacity for recognizing our own feelings and those of others, for motivating ourselves and for managing emotions well in ourselves and in our relationships" (Goleman, 2006, p. 317). EI is divided into four dimensions: self-awareness, self-management, empathy/social awareness, and relationship management (Goleman, 2013). These form the basis for developing emotional competencies required for effective organizational performance (Fernandez-Berrocal \& Extremera, 2006) and higher performance and productivity of knowledge workers (Farkas \& Török, 2011; Mozie \& Razak, 2014; Praner, 2008). Emotional competencies and EI are positively associated with organizational trustworthiness, teamwork, knowledge sharing, commitment (de Geofroy \& Evans, 2017; Goleman et al., 2013; Gujral \& Ahuja, 2011; Gurbuz, 2012; Knight et al., 2015; Lee et al., 2010; Luca \& Tarricone, 2011; Mustafa et al., 2014), and citizenship behaviour (Zamahani \& Rezaei, 2014), all of which are integral aspects of information and knowledge work.

Individuals aware of their emotions, develop mechanisms for self-evaluation, reflection, and correction (Leary, 2007). For instance, people who feel guilty tend to experience empathy towards those they harmed and are inclined to engage in corrective behaviours (Tangney, 1992). Managing one's emotions is also essential to knowledge work. For example, negative emotions hinder focused attention, which is required to enable knowledge workers' efficiency, and overall productivity (Hunter \& Scherer, 2009).

EI research, training, and practice are also beneficial to library and information management. Leaders in libraries with EI skills are better able to provide direction, build shared vision, and motivate employees to support the overall library mission (Kreitz, 2009; Porter, 2010). There is also significant evidence that they lead and manage change more effectively (Hernon, Giesecke, \& Alire, 2007; Klare, Behney, \& Kenny, 2014; Kreitz, 2009; Martin, 2016; McKeown \& Bates, 2013). Other benefits include an increase in overall productivity and effectiveness of the library 
(Kreitz, 2009; Porter, 2010; Promis, 2008), enhanced problem solving and creativity (Kreitz, 2009; Martin, 2016), the development (Martin, 2016) and adoption (Osuigwe, Ezeani, \& Anyaoku, 2013) of more innovative services, as well as more effective customer service (McKeown \& Bates, 2013). In addition, library leaders with EI competencies are better at building staff relationships (Porter, 2010; McKeown \& Bates, 2013) and manage higher performing and more efficient teams (Khan, Masrek, \& Nadzar, 2015; Kreitz, 2009; Porter, 2010; Martin, 2016; Wilkinson, 2015). These libraries also have better job environments (Khan, Masrek, \& Nadzar, 2015; Osuigwe, Ezeani, \& Anyaoku, 2013), with higher moral, trust (Porter, 2010, Promis, 2008; Wilkinson, 2015), commitment (Khan, Masrek, \& Nadzar, 2014), and reduced employee turnover (Porter, 2010).

However, library managers rarely receive formal management training as part of their library degrees, and even less guidance in managing and motivating employees, which requires strong EI skills (Khan, Masrek, \& Nadzar, 2015; Porter, 2010; Promis, 2008). Further, despite acknowledging the need for such skills (Lynch, 2001), it does not appear that libraries are soliciting EI competencies when hiring (Promis, 2008), or training these soft skills to employees once they are hired (Porter, 2010). Nevertheless, EI skills are vital, as libraries are increasingly using project teams (Promis, 2008), which require employees to effectively manage their own emotions and those of their coworkers (Martin, 2016).

\section{Analyzing Existing EI Training Programs}

EI training programs are increasingly being embraced by information and knowledge-based organizations (Cherniss et al., 1998; Goleman, 1995; Mayer \& Salovey, 1997). However, there is no consensus on the criteria for a holistic training program (Beigi \& Shirmohammadi, 2010; Grant, 2007; Riggio \& Lee, 2007), possibly because there is no consensus on a conceptualization of EI (Beigi \& Shirmohammadi, 2010). Moreover, not all authors are explicit about the theoretical foundations on which they developed their program.

Building on the work of McEnrue, Groves, and Shen (2010), who critically examined twelve empirically tested EI training programs, a search of the literature on EI training was conducted across, Google Scholar, all the ProQuest databases, ERIC and Emerald. The search terms included: "emotional intelligence", "emotional competence", "social competence", "emotional intelligence training", "training", "teaching" and "programs". Considering the limited amount of research on the topic, no publication date was set as a search criterion. In total, twenty EI training studies were retrieved.

McEnrue et al. (2010) suggested the importance of "well-designed 'clinical trials" of EI assessment and development tools" (p. 9); therefore, each study showed evidence of empirically testing a training program. The authors also suggest other important inclusion criteria, such as evidence of "the conceptual model of EI employed, the measure that served as the criterion, participants, duration of training, nature of activities, experimental design, and outcome reported by researchers." (p. 9). Using a similar analysis, comparisons were made across all twenty training programs, identifying common characteristics in theory, duration, procedure (activities, lectures, workshops), and assessment.

Despite a variety in EI training approaches, many of the programs shared commonalities. The following common characteristics are discussed below: 1) theoretical foundations; 2) duration; 3 ) grounding in self-awareness; 4) combining theory and practice; 5) combining individual and team learning; and 6) incorporating assessment and feedback (see Table 1 for more detail). 
Table 1: Summary of EI Training Study Results

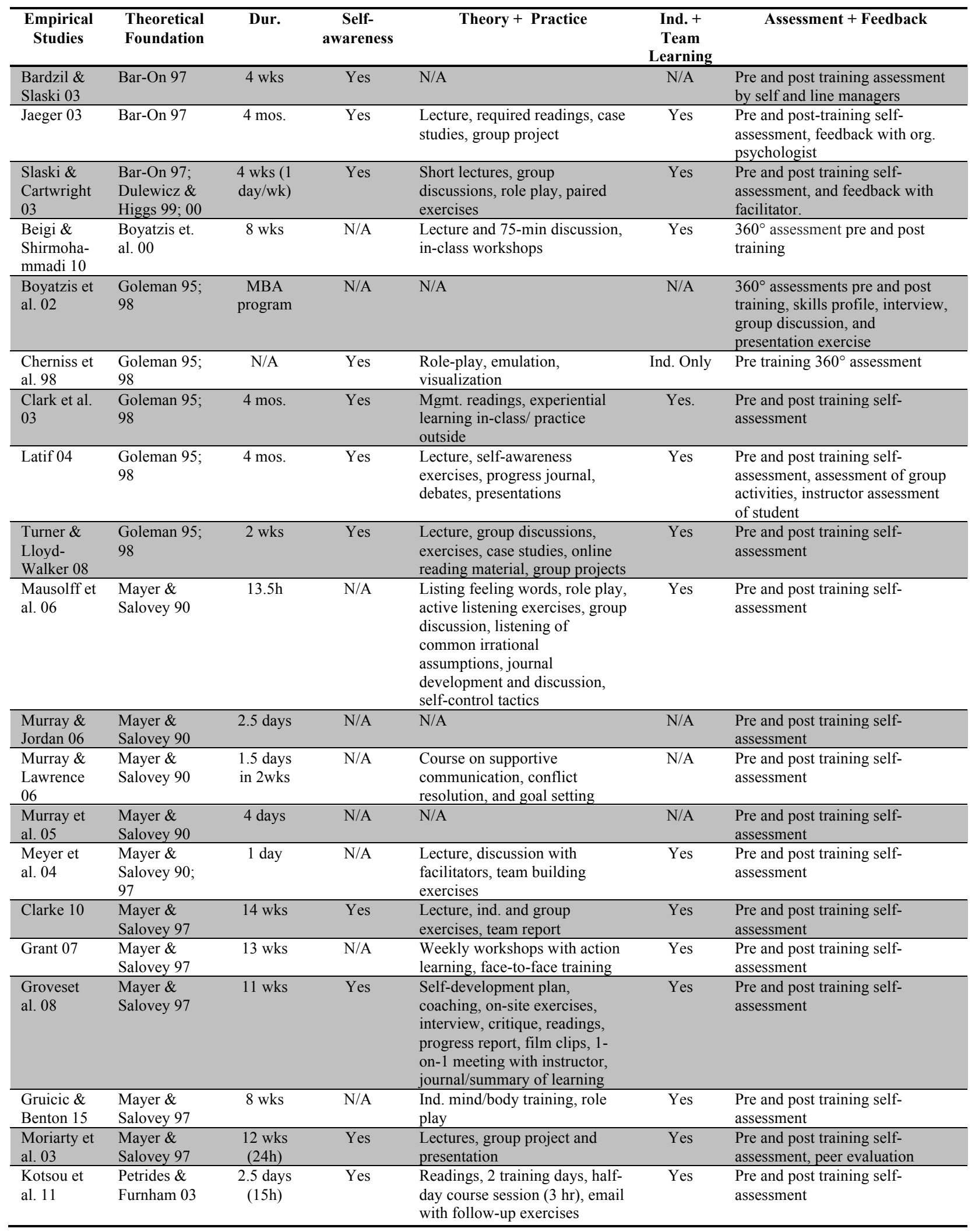


Theoretical Foundations: The ability-based model (Mayer \& Salovey, 1997) appears to be the most empirically tested theoretical foundation for developing EI training programs, because it conceptualizes EI as a set of interrelated abilities (versus personality traits or dispositions), which suggests that they can be improved through training (Wong et al., 2007). Furthermore, the conceptualization of EI determines its measurement and, unlike self-reported EI measurement tools, ability-based ones are less susceptible to social desirability effects and faking (Clarke, 2010; Whitman et al., 2008). Moreover, the ability-model is differentiable from measures of personality and cognitive intelligence (Ashkanasy \& Daus, 2005; Day \& Carroll, 2004; Groves et al., 2008; O’Conner \& Little, 2003; Palmer et al., 2005). Ability-based measurement tools also distinguish between the actual development of EI abilities and the mere motivation to use those abilities (Clarke, 2010).

Program Duration: While arguments exist for short training programs (Kotsou et al., 2011), Grant (2007) demonstrated that longer (e.g., spaced 13-week) programs provide a larger improvement of EI abilities than, for example, a 2-day block-intensive program (see Beigi \& Shirmohammadi, 2010). Depending on their complexity, certain EI competencies take longer to develop and/or improve, with some requiring 3 to $6+$ months of practice (Beigi \& Shirmohammadi, 2010; Goleman, 2006). Goleman (2006) argues, the longer the training, the more EI competencies can be developed and/or improved.

Grounding Self-awareness: Self-awareness is the cornerstone of EI (Bar-On, 1997; Goleman, 1995; 2013) and foundational for successful EI training (Clarke, 2010; Groves et al., 2008; Kotsou et al., 2011; McKeown \& Bates, 2013; Moriarty et al., 2003; Slaski \& Cartwright, 2003). Since it is a prerequisite of self-management, empathy, and effective relationship-management, it is an important starting point for all EI training (Goleman, 2013). Individuals must be aware of their own emotions in order to learn how to regulate them (Goleman, 2013; Kotsou et al., 2011).

Combining Theory and Practice: Many EI training programs provide limited information regarding the nature of their specific interventions (e.g., activities, workshops, lectures, etc.) (Beigi \& Shirmohammadi, 2010). However, programs designed exclusively around theory-based learning are not effective in changing behaviour or breaking/replacing long-established habits (Moriarty \& Buckley, 2003), because behavioural changes require regular practice. Developing EI competencies requires experiential methods, such as role-play (e.g., replaying an incident), emulation (i.e., observing and imitating behaviour), and visualization (e.g., anticipating stressful situations and adopting adequate behaviours) (Cherniss et al., 1998; Goleman, 2004). Other practical training activities include film clips, diary keeping, and paired exercises (Groves et al., 2008; Latif, 2004; Mausolff et. al, 2006; Slaski \& Cartwright, 2003). Furthermore, EI improvement depends on practice intensity (i.e., the time spent on practicing is more important than the frequency) (Clarke, 2010; Gruicic \& Benton, 2015).

Combining Individual and Team Learning: Self-motivation and commitment to training is required for developing EI competencies and for behavioural change to occur (Cherniss et al., 1998). However, the best results are obtained when individual learning is combined with teambased learning (Clarke, 2010). Team-based learning is conducive to the development of emotional abilities, because team environments generate substantial emotional experiences (Clarke, 2010; Groves et al., 2008; Moriarty \& Buckley, 2003).

Valuing Assessment and Feedback: All the programs measure improvement with an EI assessment at the beginning and the end of training. Since it is difficult for individuals to objectively reflect on their learning, Cherniss et al. (1998) suggest using a third party to assess 
the individual (e.g., a 360-degree evaluation), since third party feedback reduces the potential for biases (Moriarty \& Buckley, 2003). Assessments should be accompanied by frequent feedback throughout the program, as a significant motivator for change (Cherniss et al., 1998). This is particularly true when feedback is implemented along the right support structure (e.g., coaches, mentors, etc., who help the learner sustain their motivation and practice EI competencies) (Cherniss et al., 1998; Slaski \& Cartwright, 2003).

A full-length manuscript will elaborate on these commonalities and outline techniques for training specific emotional competencies. Future research can then test this EI training program framework using quantitative and experimental approaches.

\section{REFERENCES}

Arvey, R. \& Murphy, K. (1998). Performance evaluation in work settings, Annual Review of Psychology, 49, 141 - 168.

Ashkanasy, N. M. \& Daus, C. S. (2005). Rumors of the death of emotional intelligence organizational behavior are vastly exaggerated. Journal of Organizational Behavior, 26(4), 441-452.

Beigi, M. \& Shirmohammadi, M. (2010). Training employees of a public Iranian bank on emotional intelligence competencies. Journal of European Industrial Training, 34(3), 211225.

Bogdan, A. (2008). Motivational issues in knowledge work. Revista Informatica Economică, 4(48), 36-38.

Cherniss, C., Goleman, D., Emmerling, R., Cowan, K. \& Adler, M. (1998). Bringing emotional intelligence to the workplace: A technical report issued by the Consortium for Research on Emotional Intelligence in Organizations. The Consortium for Research on Emotional Intelligence in Organizations, Piscataway, NJ. Retrieved from http://www.eiconsortium.org/pdf/technical_report.pdf

Clarke, N. (2010). Developing emotional intelligence abilities through team-based learning. Human Resources Development Quarterly, 21(2), 119-137.

Elfenbein, H. A. (2007). Emotion in organizations. Academy of Management Annals, 1(1), $315-$ 386.

Day, A. \& Carroll, S. (2004). Using an ability-based measure of emotional intelligence to predict individual performance, group performance, and group citizenship behaviors. Personality and Individual Differences, 36, 1443-1458.

de Geofroy, Z., \& Evans, M. M. (2017). Are emotionally intelligent employees less likely to hide knowledge?. Knowledge and Process Management, 24(2), 81-95. doi:10.1002/kpm.1532

Farkas, M. F., \& Török, L. G. (2011). Knowledge workers, competencies, virtuality and management. Journal of Management Studies, 4, 67-77.

Fernández-Berrocal, P., \& Extremera, N. (2006). Emotional intelligence: A theoretical and empirical review of its first 15 years of history. Psicothema, 18(SUPPL.1), 7-12. 
Goleman, D., Boyatzis, R., \& McKee, A. (2013). Primal leadership: realizing the power of emotional intelligence. Boston, MA: Harvard Business School Press.

Goleman, D. (2006). Working with emotional intelligence. New York: Bentam Books.

Grandey, A. A. (2000). Emotion regulation in the workplace: A new way to conceptualize emotional labor. Journal of Occupational Health Psychology, 5(1), 95-110.

Grant, A. M. (2007). Enhancing coaching skills and emotional intelligence through training. Industrial and Commercial Training, 39(5), 257-266.

Groves, K. S., McEnrue, M. P., \& Shen, W. (2008). Developing and measuring the emotional intelligence of leaders. Journal of Management Development, 27(2), 225-250.

Gruicic, D., \& Benton, S. (2015). Development of managers' emotional competencies: Mind body training implication. European Journal of Training and Development, 39(9), 798814.

Hernon, P., Giesecke, J., \& Alire, C. (2007). Academic librarians as emotionally intelligent leaders. Santa Barbara, CA: Libraries Unlimited.

Hunter, J., \& Scherer, J. S. (2009). Knowledge worker productivity and the practice of self management. In Maciariello, J. A., Pearce, C. L. \& Yamawaki, H. (Eds.), The Drucker Difference: What the World's Greatest Management Thinker Means to Today's Business Leaders (175-194). New York: McGraw-Hill.

Khan, A., Masrek, M. N., \& Nadzar, F. M. (2014). The relationship between emotional intelligence and organizational commitment of Pakistani university librarians. Pakistan Journal of Information Management \& Libraries, 15(1). 11-21.

Khan, A., Masrek, M. N., \& Nadzar, F. M. (2015). An investigation of the training needs on emotional intelligence of academic librarians. Library Review, 64(8/9), 597-613.

Klare, D., Behney, M., \& Kenney, B. F. (2014). Emotional intelligence in a stupid world. Library Hi Tech News, 31(6), 21-24.

Kotsou, I., Grégoire, J., \& Mikolajczak, M. (2011). Emotional plasticity: Conditions and effects of improving emotional competence in adulthood. The Journal of Applied Psychology, 96(4), 827-839.

Kreitz, P. A. (2009). Leadership and emotional intelligence: A study of university library directors and their senior management teams. College \& Research Libraries, 70(6), 531554.

Leary, M. R. (2007). Motivational and emotional aspects of the self. Annual Review of Psychology, 58, 317-344.

O’Conner, R. \& Little, I. (2003). Revisiting the predictive validity of emotional intelligence: self-report versus ability-based measures. Personality and Individual Differences, 35 , 1893-902.

Lynch, B. L. (2001). The changing nature of work in academic libraries. College \& Research Libraries, 62(5), 407-420.

Martin, J. (2016). Emotionally intelligent leadership at 30 rock: What librarians can learn from a case study of comedy writers. Journal of Library Administration, 56(4), 345-358. doi: $10.1080 / 01930826.2015 .1105077$ 
Mayer, J. D., \& Salovey, P. (1997). What is emotional intelligence? In P. Salovey D. Sluyter (Eds.), Emotional development and emotional intelligence: Education implications (pp.331). New York: Basic Books.

Mayer, J. D., Salovey, P., \& Caruso, D. R. (2002). Mayer-Salovey-Caruso Emotional Intelligence Test (MSCEIT): User's manual. Toronto, Canada: Multi Health Systems.

McEnrue, M. P., Groves, K. S., \& Shen, W. (2010). Emotional intelligence training: Evidence regarding its efficacy for developing leaders. Leadership Review, 10, 3-26.

McKeown, A., \& Bates, J. (2013). Emotional intelligent leadership: Findings from a study of public library branch managers in Northern Ireland. Library Management, 34(6-7), 462485. doi:10.1108/LM-10-2012-0072

Moriarty, P., \& Buckley, F. (2003). Increasing team emotional intelligence through process. Journal of European Industrial Training, 27(2), 98-110.

Mozie, M., \& Razak, A. (2014). Managing knowledge worker behavior via emotional intelligence and quality of work life. Proceedings from the Knowledge Management International Conference (KMICe). (August), 12-15. Malaysia. Retrieved from http://www.kmice.cms.net.my/ProcKMICe/KMICe2014/PDF/PID119.pdf

Osuigwe, N.E., Ezeani, C. \& Anyaoku, E.N. (2013). Emotional intelligence of library leaders and innovative library services in South East Nigeria. Information and Knowledge Management, 3(10), 42-51.

Palmer, B., Gignac, G., Manocha, R., \& Stough, C. (2005). A psychometric evaluation of the Mayer-Salovey-Caruso emotional intelligence test version 2.0. Intelligence, 33, 285-305.

Porter, B. (2010). Managing with Emotional Intelligence. Library Leadership and Management, 24(4), 199-201.

Promis, P. (2008). Are employers asking for the right competencies?: A case for emotional intelligence. Library Administration \& Management, 22(1), 24-30.

Putnam, L. L., \& Mumby, D. K. (1993). Organizations, emotion and the myth of rationality. Emotion in Organization, (January 1993), 36-57.

Praner, K. J. (2008). Constructing workplace value identity: Knowledge worker perceptions of how they are valued by their organizations. (Doctoral dissertation) Capella University

Riggio, R. E., \& Lee, J. (2007). Emotional and interpersonal competencies and leader development. Human Resource Management Review, 17, 418-26.

Salovey, P., \& Mayer, J. D. (1990). Emotional intelligence. Imagination, Cognition and Personality, 9, 185-211.

Slaski, M., \& Cartwright, S. (2003). Emotional intelligence training and its implications for stress, health and performance. Stress and Health, 19(4), 233-239.

Stephens, D. \& Russell, K. (2004). Organisational development, leadership, change, and the future of libraries. Library Trends, 53(1), 239-248.

Tangney, J. P. (1992). Situational determinant of shame and guilt in young adulthood. Personality and Social Psychology Bulletin, 18, 199-206. 
Turner, R., \& Lloyd-Walker, B. (2008). Emotional intelligence (EI) capabilities training: Can it develop EI in project teams? International Journal of Managing Projects in Business, 1(4), 512-534.

Whitman, D.S., Rooy, D. L., Viswesvaran, C. \& Alonso, A. (2008). The susceptibility of a mixed model measure of emotional intelligence to faking: A Solomon four-group design. Psychology Science, 50(1), 44-63.

Wilkinson, F. (2015). Emotional intelligence in library disaster response assistance teams: Which competencies emerged? College and Research Libraries, 76(2), 188-204.

Wong, C.S, Foo, M., Want, C., \& Wong, P. (2007). The feasibility of training and development of EI: An exploratory study in Singapore, Hong Kong and Taiwan. Intelligence, 35(2), 141150.

Zamahani, M., \& Rezaei, F. (2014). The impact of managers' self-awareness, positivity and psychological ownership on organizational citizenship behavior. International Review of Management and Business Research Journal, 3(3), 1355-136. 